\title{
DETERMINĂRI GEOPOLITICE ALE RUSIEI LA MAREA NEAGRĂ
}

\author{
RUSSIA'S GEOPOLITICAL DETERMINATIONS \\ IN THE BLACK SEA
}

\section{Drd. Ilie-Răsvan DUMITRU*}

\begin{abstract}
În prezentul articol se va analiza proiecția puterii economice și militare a Rusiei în regiunea Mării Negre, văzută atât prin prisma resurselor imense ale acesteia, cât și ca mijloc de proiecție a puterii militare în statele riverane și în Mediterana de Est. Perspectiva energetică este fundamentală în geopolitica Rusiei, iar regiunea Mării Negre este percepută de aceasta ca punct de confluență a mai multor interese globaliste, în care Rusia își dorește să fie nu doar mediator, ci pivotul determinant care să impună politica regională. Crearea unei dependențe energetice a Occidentului față de resursele rusești reprezintă un scop politic bine definit în strategia rusească. Gazele rusești devin astfel un veritabil cal troian prin care Rusia poate influența politicile europene, acest instrument energetic fiind completat și de alte instrumente de forță, menite să submineze sau să diminueze rolul NATO în Europa de Est. Interesele rusești se concentrează, în primul rând, pe dorința de a menține diferite niveluri de influență politică și economică în fiecare stat riveran, de a menține Marea Neagră sub control în privința exporturilor de petrol sau gaze naturale și a altor transporturi maritime prin portul Novorossiysk, precum și pe dorința de a preveni un deficit de securitate față de NATO, care ar putea amenința flancul de sud-vest al Kremlinului. În urmărirea acestor interese, strategia Rusiei se bazează pe utilizarea instrumentelor politice, diplomatice, informaționale și economice, care sunt susținute de o capacitate militară din ce în ce mai credibilă, aspecte care vor fi analizate și explicate în acest articol.
\end{abstract}

The present paper analyzes the projection of Russia's economic and military power in the Black Sea region, seen both in terms of its huge resources and as a way of projecting military power in the coastal States and the Eastern Mediterranean. The energy perspective is important in Russia's geopolitics, and the Black Sea region is perceived by it as the point of confluence of several globalist interests, in which Russia desires not only to be a mediator, but the decisive pivot to impose regional policy. Creating an energy dependency of the West on Russian resources represents a well-defined political goal in the Russian strategy. Russian gas is thus becoming a Trojan horse, by which Russia can influence European policies, this energy instrument being complemented by other powerful instruments aimed at undermining or diminishing NATO's role in Eastern Europe. Russian interests are concentrating firstly on the desire to maintain different levels of political and economic influence in each coastal State, to maintain the Black Sea under control for oil or gas exports and other maritime transport through Novorossiysk port as well as preventing a security deficit toward NATO that could threaten the South-West flank of Kremlin. In pursuing these interests, Russia's strategy is based on the use of political, diplomatic, information and economic instruments, which are supported by an increasingly credible military capacity, analyzed and explained in this paper.

Cuvinte-cheie: războiul ruso-ucrainean; Crimeea; arma energetică; Marea Neagră.

Keywords: Russian-Ukrainian war; Crimea; energy weapon; Black Sea.

\section{Considerații generale}

Pentru a analiza conduita actuală a Rusiei, motivația și interesele geopolitice ale acesteia, va trebui să plecăm de la cuvintele lui Churchill, din discursul de la Colegiul Westminster, Fulton, Missouri, din 5 martie 1946: „După cum i-am văzut pe prietenii și aliații noștri ruși în timpul războiului, sunt convins că nu există nimic pe care să-1 admire

\footnotetext{
*Universitatea Națională de Apărare „Carol I” e-mail:dumitrurasvan@yahoo.com
}

atât de mult ca forța și nu există nimic pentru care să aibă mai puțin respect decât slăbiciunea, în special slăbiciunea militară" ". Churchill a intuit perfect caracterul specific al politicii rusești, neschimbat de secole, exprimându-și opinia că Rusia nu dorește neapărat războiul, avertizând însă că Moscova dorește roadele războiului și extinderea nedeterminată a puterii și a politicilor sale ${ }^{2}$.

Rusia este statul cu cea mai mare suprafaţă teritorială $\left(17.125 .191 \mathrm{~km}^{2}\right)$, care se întinde din Europa de Est până în Asia de Nord, pe 17 fusuri orare. Rusia europeană se află la vest de munții 
Ural, iar partea asiatică este reprezentată de Siberia, care se întinde la est de lanţul muntos, până la Marea Bering și Oceanul Pacific. Prin mărimea și complexitatea acesteia, Rusia prezintă un puternic caracter discordant. Deși acoperă o optime din suprafața terestră locuibilă a lumii, ea ocupă doar locul nouă între cele mai populate state din lume. Totuși, chiar dacă $75 \%$ din teritoriul acesteia se află pe continentul asiatic, această regiune este populată cu doar $22 \%$ din populația totală a statului. Şi, deși cea mai mare parte a teritoriului se află pe continentul asiatic, Rusia având graniţă comună cu Kazahstanul, Mongolia, China, Coreea de Nord, inclusiv graniță maritimă cu Japonia și SUA, ea nu este o putere asiatică, ci mai mult o putere europeană, dat fiind că este o prelungire a Europei şi că, la vest de munţii Ural, se concentrează cea mai mare parte a activității economice ruse. Chiar și așa, în afara teritoriului tradiţional rusesc, constituit în timpul lui Ivan cel Groaznic (1533-1584), o parte din populația Federației Ruse este formată din alte naționalităţi: ucraineni, bașkiri, ciuvași și alte naționalităţi. Această eterogenitate a populației a necesitat un regim de control mai strict al ei, situaţie ce se regăsește inclusiv în perioada Uniunii Sovietice. Siberia reprezintă însă comoara plină de resurse a Rusiei, care constă în enorme zăcăminte de minereuri, petrol și gaze, fapt ce determină ca, în actuala competiție globală, acerbă, pentru resurse, arma preferată a Rusiei să fie cea energetică.

Proiecția puterii economice a Rusiei în regiunea Mării Negre trebuie văzută prin prisma resurselor imense ale acesteia şi mai puţin prin activitatea economică. Acest fapt îi imprimă şi politica regională, uneori agresivă, față de Occident și, cu precădere, față de statele aflate în proximitatea frontierelor acesteia. Perspectiva energetică este fundamentală în geopolitica Rusiei, iar regiunea Mării Negre este percepută de aceasta ca punct de confluență a mai multor interese globaliste, în care Rusia își dorește să fie nu doar mediator, ci pivotul determinant care să impună politica regională. Îngrădirile impuse de dreptul conflictelor armate și încorsetarea frontierelor de Alianța Nord-Atlantică și de țările occidentale îi limitează dreptul ancestral pe care Rusia și-1 arogă, de a se impune militar, dar și economic. Acest aspect se datorează faptului că dimensiunea economică a Federației nu se află nici la nivelul la care să se poată impune, nici la nivelul la care să se poată dezvolta, ca în timpul
Războiului Rece. Totuși, Rusia se folosește de resursele energetice, pentru a le transforma în cea mai eficientă armă prin care își poate impune politica regională. Crearea unei dependențe energetice a Occidentului față de resursele rusești reprezintă un scop politic bine definit în strategia rusească $\breve{a}^{3}$. Gazele rusești devin astfel un veritabil cal troian prin care Rusia poate influența politicile europene; dar doar resursa energetică nu este suficientă pentru reafirmarea Rusiei ca mare putere regională, dacă nu este însoțită și de alte instrumente de forță care să submineze sau să diminueze rolul NATO în Europa de Est. Astfel, viziunea lui Churchill față de politica rusească, deși emisă la finele celei de-a doua conflagrații mondiale, este cât se poate de reală și în zilele noastre.

\section{Scurt istoric al formării statului rus}

Pentru Rusia, factorii geostrategici ai regiunii Mării Negre nu s-au schimbat din $1853^{4}$, NATO și Statele Unite înlocuind statele europene individuale cu principalii concurenți geopolitici ai Rusiei. În actualul context geopolitic regional, gazul rusesc reprezintă mărul otrăvit pentru Occident, Crimeea este baza de proiecție a forței militare, Turcia reprezintă pivotul, iar strâmtorile turcești reglează randamentul strategic. Astfel, obiectivul final al Moscovei este reprezentat de accesul și de prezența militară în estul Mediteranei, ca o contrabalansare a extinderii SUA și NATO spre est, precum și ca o expansiune a puterii în Marea Egee și în zona mediteraneeană centrală, pentru extinderea sferei de influență pe noua magistrală a drumului mătăsii, creionat de o Chină care aspiră la un statut hegemonic universal.

Caracterul complex, discordant, expansiv și ostil al Federației Ruse nu ar putea fi înțeles, dacă nu am pătrunde în istoria sinuoasă a acestui popor conservator, tradiţionalist, rigid și mândru. Rusia, ca formațiune societală, datează din jurul secolului al IX-lea, când triburile de slavi estici au format o protofederație, numită Rusia Kieveană, constituită din orașele din jurul Kievului și din cele de pe râul Nipru, pe teritoriul actual al Ucrainei. Invazia mongolilor din secolul al XIII-lea, precum și presiunile exercitate de aceștia asupra Rusiei Kievene au condus la o migrare spre nord-est și la o concentrare a populaţiei de etnie rusă în jurul Moscovei. Această concentrare a populației ruse a dus la formarea Marelui Cnezat al Moscovei. Cel 
care avea să desăvârșească centralizarea cnezatului, prin cucerirea regiunilor rusești Novgorod (1478) și Tver (1485), a fost Ivan al III-lea cel Mare (1462-1505). Acesta a dus o politică de expansiune moderată, extinzând puterea prin unirea teritoriilor locuite de ruși, până ce Hoarda de Aur a încetat să mai dețină puterea feudală suzerană (1480), conducând astfel la o creștere a forței, resurselor, populației și întinderii teritoriale a cnezatului. Dar această extindere teritorială avea o vulnerabilitate critică, ce era dată de formele de relief care nu asigurau o barieră protectoare eficientă împotriva eventualilor invadatori, principatul neputând fi apărat decât, eventual, de pădurile din jurul Moscovei. Lipsa unor obstacole naturale care să le permită rușilor să își organizeze apărarea a fost principalul catalizator al expansiunii teritoriale. Această politică, bazată pe ideea atacului ca apărare, a fost pusă în practică de Ivan al IV-lea cel Groaznic (1533-1584), care își arogă meritul de a fi pus bazele Rusiei țariste. În timpul domniei lui Ivan al IV-lea, țaratul a ajuns până la bariera naturală, formată de Munții Ural, la est, de Marea Caspică, la sud și de Cercul Arctic, la nord.

În secolul următor, țaratul se extinde peste bariera naturală a Munților Ural, încorporând toată Siberia până la Oceanul Pacific din Extremul Orient. Această extindere teritorială a permis Rusiei țariste să capete o adâncime strategică la care putea să apeleze, în caz de invazie. O suprafață atât de extinsă necesita mult efort logistic și o linie lungă de aprovizionare a armatelor, care putea epuiza orice forță militară care ar fi dorit să cucerească Moscova. Sub domniile lui Petru cel Mare (16821725), a cărui politică a condus la apariția Imperiului Rus (1721), precum și sub conducerea împărătesei Ecaterina cea Mare (1762-1796), Rusia țaristă s-a extins și spre vest și sud, aceasta ajungând să fie protejată de un inel uriaș de apărare, reprezentat de regiunea arctică, baltică, ținutul Ucrainei, Munții Carpați, Marea Neagră, Munții Caucaz, Marea Caspică și Munții Ural până la Cercul Arctic. Întinsul nesfârșit al Siberiei, climatul ei sărăcăcios și rece, stepele deșertice ale Mongoliei de Nord au reprezentat o zonă tampon uriașă, naturală în fața eventualilor atacatori; geografia era cea care asigura imperiul că nu va putea fi atacat dinspre est de nicio armată inamică.

Geografia extinsă a Rusiei a prezentat și prezintă două mari regiuni fierbinţi asupra cărora actorii ostili acesteia au generat dintotdeauna presiune. Una este reprezentată de Câmpia Europei de Nord, care se întinde din Franța până la Munții Ural, iar a doua este reprezentată de regiunea Mării Negre. În ceea ce privește Câmpia Europei de Nord, aceasta se întinde din nord-vestul Franței, cuprinde Belgia, Olanda, nordul Germaniei și toată Polonia. La granița cu Rusia, Câmpia de Nord Europeană, care se unește cu Câmpia Rusească, formând împreună Câmpia Europeană, are 3.200 km lățime și reprezintă o regiune plată până dincolo de Moscova. Tocmai acest relief plat al acestei suprafețe mari de pământ a permis ca efective mari de trupe ostile să le poată parcurge relativ ușor din punctul de vedere al mobilității, dar extrem de greu, raportat la liniile mari de aprovizionare a armatelor și la clima imprevizibilă. Dinspre această câmpie, în ultimii 500 de ani, Occidentul a atacat Rusia; prima dată polonezii ${ }^{5}$, urmați de armata suedeză, condusă de Carol al XII-lea ${ }^{6}$, de armatele napoleoniene ${ }^{7}$, și de germani, în cele două conflagrații mondiale. Intinderea nesfârșită a Rusiei, dificultăţile de aprovizionare a trupelor şi clima capricioasă 1-au determinat pe ilustrul general francez A. H. Jomini, care 1-a însoțit pe Napoleon în campania din 1812, să lase moștenire ceea ce avea să dea de gândit multor comandanți de armate: „Rusia este o ţară în care intri uşor, dar din care ieşi foarte greu"».

O serie de factori politici, economici și militari, i-au determinat pe liderii ruși să caute și să menţină influența în regiunea Mării Negre, pentru preluarea controlului asupra zonei. De la sfârșitul secolului al XVI-lea până în secolul al XX-lea, Imperiul Rus a purtat 12 războaie cu Imperiul Otoman", care dorea extinderea sferei de influență politică și economică, în special în Peninsula Crimeea. O bază permanentă în Crimeea i-ar fi permis controlul asupra stepelor kievene, Câmpiei Europei de Nord, regiunii Astrahanului și Mării Azov. Marea Neagră a prezentat interes major și pentru Rusia, datorită necesităţii accesului navelor militare într-un port cu ape calde, care nu îngheață iarna și care oferă acces liber la rutele comerciale importante ale lumii ${ }^{10}$. Portul de la Oceanul Arctic (Murmansk), precum și cel de la Oceanul Pacific (Vladivostok) sunt inaccesibile câteva luni pe an, din cauza ghețurilor, ceea ce afectează atât comerțul, cât și accesul flotei ruse, blocându-i astfel orice acțiune ca mare putere navală globală. Lipsa unui port 
cald, care să permită accesul liber la oceanele lumii a devenit o problemă importantă, fiind catalogată drept vulnerabilitate strategică, încă de pe vremea lui Petru cel Mare. Forțarea accesului la Marea Mediterană și, de acolo, la Oceanul Pacific, precum și la Oceanul Indian prin cucerirea tinuturilor afgane a reprezentat un scop vital pentru politica expansionistă a Rusiei.

În timpul celui de-al Doilea Război Mondial, sovieticii au văzut Bulgaria, România și Ucraina devenind instrumente ale naziștilor, prin care s-a încercat înfrângerea Armatei Roșii din sudul Rusiei, în scopul de a se prelua controlul asupra câmpurilor petrolifere din zona Caucazului. În această perioadă, Uniunea Sovietică și-a extins sfera de influență în regiunea Mării Negre, prin modificări teritoriale (reanexarea Basarabiei ${ }^{11}$ ) și prin sprijinirea instaurării guvernelor comuniste din Bulgaria și România, care au fost forțate să se alinieze la politica Moscovei. Înființarea Pactului de la Varșovia în 1955, ca răspuns la formarea Organizației Tratatului Nord-Atlantic a consolidat și mai mult poziția Uniunii Sovietice în regiune. Trupele sovietice rămase în România după $1945 \mathrm{au}$ fost retrase abia în 1958, nu însă înainte de a sărăci, de a devaliza de resurse și de a promova o politică feroce, de subjugare economică a României, disimulată prin înființarea unor companii mixte numite sovromuri. În perioada Războiului Rece, Uniunea Sovietică s-a bucurat de o preeminență politică, militară și economică de la Burgas la Batumi. Presiunile Rusiei exercitate asupra Turciei, pentru preluarea controlului asupra strâmtorilor, au condus la aderarea Turciei la NATO, în 1952. Acest fapt a fost compensat prin mărirea capacității SUA și a altor forțe aliate de a opera din bazele militare înfiinţate în Turcia, impunând astfel un echilibru regional de putere, pe care Moscova a fost nevoită să îl recunoască.

\section{Considerații asupra geopoliticii ruse actuale}

Din punct de vedere politic, sovieticii au perceput pătrunderea capitalismului democratic în Europa de Est ca pe o amenințare existențială la adresa Uniunii Sovietice. Prăbuşirea acesteia a privat Federația Rusă de o mare parte din influența și securitatea regională pe care o deținea în regiunea Mării Negre. Loialitatea politică a foștilor aliați riverani la Marea Neagră s-a dovedit fragilă, odată cu prăbușirea URSS. Deși, prin Tratatul de prietenie încheiat cu Ucraina, la 31 mai 1997, Federația
Rusă și-a menținut flota Mării Negre în porturile militare din jurul peninsulei Crimeea, fenomenul revoluțiilor colorate, cea a trandafirilor din Georgia (noiembrie 2003), cea portocalie din Ucraina (noiembrie 2004) sau cea eșuată din Republica Moldova (aprilie 2009), au fost percepute ca o imixtiune a Occidentului în politica geostrategică a Rusiei. Statutul de membru cu drepturi depline în NATO (2004) și în Uniunea Europeană (2007), acordat Bulgariei și României (foste țări membre ale Pactului de la Varşovia), precum și apelul președintelui american George Bush ${ }^{12}$, prin care i-a îndemnat pe alți lideri ai NATO să declare că Georgia și Ucraina se vor alătura alianței militare ${ }^{13}$, a îngrijorat autoritățile Federației Ruse, acestea simțindu-se obligate să ia măsuri. Intervenția în forță în Georgia ${ }^{14}$ (2008) a deteriorat semnificativ relațiile Rusiei cu Occidentul și, în special, cu Statele Unite. De altfel, la conferinţa pentru securitate de la München (2007), Putin avertizase țările occidentale cu privire la extinderea NATO în zona de proximitate a Federației Ruse ${ }^{15}$, criticând ceea ce el a numit dominația monopolistă a Statelor Unite în relatiile globale și „utilizarea aproape necontenită a forței în relațiile internaționale". Având în vedere declinul relativ rapid al influenței ruse în regiunea Mării Negre, Rusia a fost forțată să-și reconsidere rolul de putere regională și să dezvolte o nouă strategie pentru a-și proteja interesele în regiune, chiar înainte de 2014. Anexarea ilegală a Crimeii, în 2014, a forțat Kremlinul să adopte măsuri urgente pentru a diminua efectele măsurilor dispuse de Occident.

Având în vedere intensificarea confruntării cu Occidentul, care a debutat cu războiul din Georgia (2008) și care a escaladat cu conflictul din Ucraina (2014), este important să înțelegem modul în care Rusia își configurează interesele în regiune și strategia pe care o urmărește pentru a-și asigura aceste interese strategice.

La prăbușirea Uniunii Sovietice, din rămășițele URSS au renăscut 15 state suverane. Acestea pot fi grupate pe cinci regiuni geografice:

- zona baltică: Estonia, Letonia, Lituania;

- zona Europei de Est: Belarus, Moldova și Ucraina;

- zona Caucazului de Sud: Georgia, Armenia, Azerbaidjan;

- zona Asiei Centrale: Kazahstan, Kirghizstan, Tadjikistan, Turkmenistan, Uzbekistan;

- zona euroasiatică: Rusia. 
Astfel, geografia a înlocuit ideologia sovietică, granițele statelor suverane recăpătându-și configurația logică, ce urmează linia munților, a lacurilor, a râurilor și a mărilor. Granițele tradiționale delimitează spațiile în care popoarele își vorbesc propria limbă și își respectă tradițiile izvorâte din istorie. Excepția este reprezentată de stanurile care s-au desprins din vechiul Imperiu Persan, acestea având granițele trasate artificial de Stalin, care a urmărit să slăbească puterea națională a statelor prin intercalarea unor minorităţi naționale din statele învecinate.

Aceste state desprinse din fosta URSS pot fi împărțite în trei categorii, în funcție de sfera de influenţă a Rusiei asupra politicii acestora:

- state neutre: Uzbekistan, Azerbaidjan și Turkmenistan. Acestea sunt independente energetic și nu sunt îndatorate nici Occidentului, și nici Rusiei, în privința securității și comerțului, ceea ce le determină să își reconsidere singure politicile naționale. În încercarea diminuării neutralității și a relativei independențe, Rusia a plantat conflicte înghețate ${ }^{16}$ in interiorul sau în proximitatea acestora;

- state proruse: Kazahstan, Kirghizstan, Tadjikistan, Belarus și Armenia. Toate aceste state sunt interconectate economic cu Rusia, au minorități ruse bine integrate în societate, fac parte din Uniunea Economică Euroasiatică ${ }^{17}$ (cu excepția Tadjikistanului) și din Organizația Tratatului de Securitate Colectivă - OTSC $^{18}$ (cu excepția Tadjikistanului).

- state proocidentale - Ucraina, Georgia și Moldova -, care aspiră să adere atât la NATO, cât și la UE, dar care sunt ancorate în sfera de influență a Rusiei, care le consideră incluse în conceptul aproape în străinătate, menținându-se pe teritoriul acestora, prin enclave sau regiuni autonome, ce alimentează conflicte înghețate, trupe militare sau miliții proruse.

Pe lângă acestea, celelalte state care au făcut parte din Pactul de la Varșovia sunt în NATO și $\mathrm{UE}^{19}$, respectiv: Polonia, Letonia, Estonia, Lituania, Ungaria, România, Bulgaria, Cehia, Slovacia și Albania.

Dintre toate aceste state, riverane la Marea Neagră sunt toate cele proocidentale, cu excepția Rusiei. Acest aspect explică de ce Kremlinul a intervenit atât de brutal în politica Ucrainei, pe fondul escaladării tensiunilor politice cu privire la direcția spre care se îndrepta Ucraina în anul 2013.
Înainte de conflictul din Georgia (2008), Marea Neagră a fost promovată ca un model de cooperare navală între foștii adversari ai Războiului Rece. Activitățile navale comune (BlackSeaFor și Black Sea Harmony), precum și participarea regulată a Rusiei la Operația Active Endeavor a NATO promiteau un viitor în care toate statele riverane din Marea Neagră puteau conlucra pentru a asigura un climat de securitate regională, atenuând amenințări, precum contrabanda sau traficul de persoane. Acest climat de cooperare s-a deteriorat după războiul ruso-georgian, dar elementele au fost mentinute până în 2013, ca urmare a eforturilor combinate ale Rusiei și membrilor NATO - în special Turcia. Odată cu anexarea Crimeii, cu războiul din Donbas și cu degradarea accentuată a relațiilor cu Occidentul, elementul cooperativ al strategiei militare ruse s-a orientat spre confruntarea politică și subversivă cu NATO, precum și spre concurența pentru prezența militară în regiunile Mării Negre și estului Mediteranei.

Consider că Rusia nu a dorit și nu dorește un conflict cu NATO, însă apropierea de frontiera acesteia creează destulă tensiune şi îngrijorare pentru a nu reacționa, mai ales că aceasta era avantajată de factori care puteau permite cu lejeritate lansarea unor agresiuni hibride, precum: prezența unei minorități ruse semnificative în Crimeea și proximitatea estică a Ucrainei, un climat tensionat și destabilizant, o forță militară semnificativă în vecinătatea zonei vizate, precum şi o vulnerabilitate a cadrului instituţional şi administrativ din peninsulă.

Dacă la conducerea Ucrainei s-ar fi aflat un guvern prorus sau măcar unul neutru care să nu adere la organizațiile occidentale, Rusia nu ar fi acționat brutal, deoarece ar fi avut garanţia prezervării unei zone tampon în Câmpia Europei de Nord și în Marea Neagră, care să protejeze Federația Rusă de eventualele agresiuni.Aceasta avea nevoie de garanții că baza navală de la Sevastopol nu va fi afectată de o direcție proocidentală a Ucrainei, mizând și pe faptul că dependența energetică a acesteia față de resursele ruse era un contraargument solid care să o menţină în sfera de influență a federației. Intrarea Ucrainei pe o axă prooccidentală reprezenta un risc de proximitate pentru Rusia, care ar fi putut conduce la transformarea bazei de la Sevastopol într-o bază militară NATO. Situaţia s-a tensionat, deoarece președintele Ucrainei, Viktor Ianukovici, 
a făcut greșeala de a pendula pe două fronturi, în încercarea de a obține avantaje economice și politice atât din Occident, cât și din Rusia. Acest joc a atras animozitatea populației proocidentale, care a declanșat revoluția Euromaidan, ce a condus, în final, la evenimentul din 2014. Politica duală a lui Ianukovici nu era una singulară, această strategie regăsindu-se și la Igor Dodon, Vladimir Voronin, Vladimir Plahotniuc, Aleksandr Lukașenko și liderul armean Serzh Sargsyan.

Ideea de a avea o graniță comună cu un stat membru al NATO sau UE este inacceptabilă pentru politica președintelui Putin. Înființarea unei baze militare NATO lângă o bază militară rusească (Sevastopol) este de neconceput pentru politica rusă, care vede toată această expansiune occidentală ca pe o agresiune formală la adresa politicii ruse ${ }^{20}$. După anexarea forțată a Crimeii, oricât am încerca să ne uităm în altă direcție din punct de vedere politic și militar, ceea ce se întâmplă în bazinul Mării Negre este pivotal, nu numai pentru statele din proximitate, dar și pentru Balcanii de Vest, Orientul Mijlociu, zona Mării Baltice și chiar Nordul Îndepărtat. Importanța strategică a Mării Negre este dată și de faptul că Sevastopolul este singurul port rusesc la o mare cu ape calde, ceea ce îi mărește considerabil potențialul economic și militar. Din acest port, militar, Rusia își poate exercita controlul asupra traficului naval din regiunea Mării Negre. Însă accesul în afara acestei regiuni nu este unul facil. Ieșirea la Mediterană este restricționată prin Convenţia de la Montreaux din 1938, care permite Turciei (țară membră a NATO) să controleze traficul prin strâmtoarea Bosfor. Navele militare nu pot tranzita zona decât în număr şi tonaj limitat și doar în condiții de pace. Chiar dacă reușesc să treacă de Bosfor, pentru a pătrunde în Marea Mediterană, navelor militare rusești ar trebui să li se permită accesul la Marea Egee. Mai departe, accesul la Oceanul Atlantic, din Mediterană, nu se poate poate realiza decât prin acordarea permisiunii de trecere prin strâmtoarea Gibraltar. În Oceanul Indian, nu se poate trece decât prin acordarea permisiunii de trecere prin Canalul Suez, acesta aflându-se sub controlul unei forțe multinaționale $\mathrm{MFO}^{21}$.

$\mathrm{O}$ altă dificultate strategică este aceea că flota rusă din Kaliningrad nu poate ieși din Marea Baltică decât prin strâmtoarea Skagerrak, care face legătura cu Marea Nordului, controlată de Danemarca și Norvegia (ambele state membre ale NATO).
Chiar dacă ar reuși să treacă prin acest culoar îngust, pentru accesul la Oceanul Atlantic, prin Marea Nordului, navele rusești ar trebui să treacă prin culoarul delimitat de Groenlanda, Islanda și Regatul Unit al Marii Britanii (culoarul GIUK). Toate aceste restricții limitează potențialul Rusiei de a deveni o mare forță militară navală, precum și aspirația la un statut de hegemon mondial. În această situație, interesele strategice rusești în regiunea Mării Negre se concentrează, în mare măsură, pe securitate, influență politică și economică, scopuri care reflectă statutul de mare putere.

\section{Interesele Federației Ruse la Marea Neagră}

În domeniul securităţii, forțele militare rusești din regiune se mențin pentru a proteja zonele critice pentru producția economică, pentru a interzice activitatea ilegală, pentru a realiza siguranța navigației şi a sprijini implementarea deciziilor de politică externă în zone maritime importante din punct de vedere economic, aplicaţii comune sau operații de menținere a păcii ${ }^{22}$. Strategic, forțele ruse din regiune sunt destinate să asigure flancul sud-vestic al Rusiei împotriva unui atac, să intimideze și să descurajeze vecinii de la urmărirea politicilor contrare intereselor Moscovei, chiar cu forța, dacă este necesar. Capacitatea acestor forțe de a desfășura operații în Marea Neagră a fost demonstrată prin atacul rus asupra navelor marinei ucrainene și reținerea a 24 de marinari aflaţi la bord, lângă strâmtoarea Kerch, la 25 octombrie $2018^{23}$.

Pe lângă interesele sale de securitate, Rusia urmărește interese politice în toate statele riverane din zona Mării Negre. Având în vedere că Bulgaria și România sunt membre ale UE și ambele, precum şi Turcia fac parte din NATO, influențarea politicilor acestora este mai dificilă în perioada post-Război Rece. Istoria recentă a demonstrat că influența politică rusă în Ucraina și Georgia este mai eficientă din punctul de vedere al Moscovei, prin faptul că nu au o apartenență la structurile occidentale sau Nord-Atlantice. Politica rusă constă în încercarea Moscovei de a sprijinipe cei care favorizează relațiile de prietenie cu aceasta, concomitent cu respingerea celor care nu au o politică proeuroasiatică. În ceea ce privește interesele economice ale Rusiei, Turcia şi Ucraina sunt cei mai mari parteneri comerciali ai Rusiei în regiune, cu un dever mai mare decât al celorlalte țări riverane. Astfel, în anul 2018 Turcia a avut un volum total al schimburilor comerciale 
de 26 de miliarde $\${ }^{24}$, iar Ucraina, de 11,7 miliarde $\$ 25$. Exporturile rusești către partenerii comerciali sunt axate, în primul rând, pe resurse naturale (cu precădere, gaz natural), acest aspect fiind văzut ca o armă economică eficientă de influențare a politicii altor state. Însă nu numai resursa energetică reprezintă un instrument de influențare a altor state, ci și alte produse comercializate sau chiar turismul sunt folosite pentru a influența pozitiiile statelor suverane. Astfel, la sfârșitul anului 2015, Moscova a impus sancțiuni economice ${ }^{26}$, constând în limitarea comerțului cu produse agricole, precum și restricționarea turismului în Turcia, după doborârea de către Ankara a bombardierului rusesc Su-24, care a încălcat spațiul aerian turc.

Un element cheie al modului în care Rusia își percepe interesele în regiune și modul în care aceste interese pot fi amenințate reprezintă natura relației Rusiei cu Occidentul. În primii ani ai regimului Putin, Kremlinul a căutat să adopte o relație de bună colaborare și cooperare cu Statele Unite și cu aliații săi. Chiar și după aderarea Bulgariei și României la NATO (2004) și UE (2007), a existat un anumit grad de cooperare în materie de securitate, în regiunea Mării Negre, între Rusia și Occident. Până la deteriorarea relațiilor cu Occidentul și cu Statele Unite, cu precădere după războiul georgian (2008), Rusia nu își definise clar interesele de securitate, politice și economice din regiune, oscilând între relații cu sumă zero și cele de confruntare. După criza din Ucraina, degradarea accentuată a relațiilor cu Occidentul a condus la reconsiderarea politicii de securitate a Rusiei, expansiunea UE și NATO fiind percepută ca o amenințare la adresa stabilității statului rus ${ }^{27}$. În același timp, poziția Rusiei poate fi văzută ca un act de persuasiune prin afișarea unui grad minim de influență pe care aceasta crede că trebuie să îl mențină în vecinătatea sa, indiferent de starea relațiilor cu Occidentul.

În ceea ce privește obiectivele Federației Ruse la Marea Neagră, documentele strategice oficiale, reprezentate de doctrinele militare și de strategiile de securitate națională ale Rusiei, nu menţionează detalii semnificative privind direcția geopoliticii rusești în regiunea Mării Negre. Politica acesteia poate fi însă dedusă pe baza intereselor și comportamentului său, din care să reiasă ecartul dintre dorință și acceptanță, respectiv ce ar prefera și ce ar accepta Rusia. De la venirea lui Vladimir Putin la conducerea Rusiei, acesteia i s-a reimprimat de facto statutul de mare putere euroasiatică. Această calitate hegemonică pretinsă de Rusia pare să însemne că liderii ruși ar prefera să beneficieze de o sferă de influență privilegiată prin stabilirea unui mecanism de reintegrare a fostelor republici sovietice în structuri euroasiatice, cu excepția statelor baltice (Estonia, Letonia și Lituania).

În regiunea Mării Negre, acest proiect de reintegrare conferă Rusiei o mai mare securitate, influență politică și economică în Ucraina și Georgia (precum și în Moldova și Armenia). Rezultatul final poate îmbrăca o diversitate de forme, dar obiectivul principal al Rusiei rămâne menținerea influenței în Ucraina și Georgia și împiedicarea, prin orice mijloace, a integrării acestora în structurile occidentale și nord-atlantice. Având în vedere deteriorarea relațiilor cu Occidentul și reacția Statelor Unite după evenimentele din 2008 și 2014, Rusia ar putea continua să accepte guverne orientate spre Vest la Kiev și Tbilisi, atâta timp cât aceste țări își reconsideră poziţia față de NATO sau UE.

Referitor la politica Bulgariei, României și Turciei, care sunt deja integrate în NATO, perspectivele de a le modifica drastic orientarea geopolitică sunt aproape nule, Rusia nefiind dispusă să urmărească acest lucru care nu duce la niciun rezultat. Politica Rusiei trădează însă acțiuni care urmăresc, probabil, să submineze sau să contracareze orice politici antirusești, percepute ca provenind din interiorul regiunii, sprijinind orice oportunitate care promovează interesele rusești în regiunea Mării Negre. Scopul politic al Kremlinului este de a sprijini liderii, în special din Ankara și Sofia, care au o poziție tolerantă pentru un angajament mai mare cu Rusia și care sunt dispuși să acționeze în moduri care seamănă diviziune și incertitudine în Occident.

În esență, Rusia dorește ca regimul de conducere din fiecare țară riverană membră a NATO să respecte statutul Rusiei, de putere regională, și să nu permită dezvoltarea unei situații de securitate care amenință în mod legitim flancul de sud-vest al acesteia. În viziunea Rusiei, o posibilă integrare a Ucrainei, Moldovei sau Georgiei în structurile NATO și UE este văzută ca o amenințare pe termen lung, care urmărește să submineze Uniunea Economică Euroasiatică prin alimentarea unei influențe politice occidentale la granițele Rusiei. Perspectiva unei asemenea 
integrări ar justifica promovarea intereselor rusești în toate domeniile cheie, care ar afecta, cel puțin, politicile statelor riverane. Această viziune este subliniată de intervențiile militare rusești în ambele țări, începând cu 2008.

Strategia Federației Ruse la Marea Neagră se bazează pe întrebuințarea unei combinații de instrumente nonmilitare și militare, al căror conținut și aplicare depind de contextul și orientarea politică a fiecărei țări. Strategia politică regională a Rusiei se adaptează în mare măsură în funcție de factori cheie, precum istoria, cultura, considerațiile de securitate și realitățile geopolitice actuale. Rusia pune un accent deosebit pe fostele republici sovietice, care, pe lângă faptul că se încadrează în politica „aproape în străinătate”, au o minoritate rusă semnificativă, sunt contigue și împărtășesc o cultură și o istorie comune. În 2013, Rusia a făcut un efort susținut şi direcționat pentru a descuraja Ucraina și Georgia (și Armenia și Moldova) de la semnarea acordurilor de asociere în Zona de Liber Schimb Aprofundat și Cuprinzător - ZLSAC cu UE. Aceste demersuri au determinat Armenia să abandoneze, în 2013, în mod neașteptat, urmărirea unui acord de asociere, alăturându-se Uniunii Economice Eurasiatice. Rusia a căutat, probabil, o inversare similară a parcursului occidental în Kiev și Tbilisi, dar nu a reușit să atingă acest obiectiv. Putin a susţinut, într-un interviu documentar din 2015, că Occidentul încearcă în mod deliberat să submineze aşa-numitele eforturi de integrare eurasiatică ale Rusiei ${ }^{28}$. Din punctul de vedere al Georgiei, Moldovei și Ucrainei, apropierea de UE, mai stimulantă economic, a fost mai atractivă decât aderarea la Uniunea Economică Eurasiatică, relativ mai săracă, pe care Rusia a căutat să o domine pentru propriile interese. Pentru a schimba politicile pe care Moscova le considera nesatisfăcătoare, Rusia a desfășurat o gamă variată de activități politice, informaţionale, economice și clandestine în aceste țări șiînalte țări din regiune. De exemplu, în Bulgaria, Rusia a folosit elemente de istorie, de cultură și de religie pentru a susține iniţiativele rusești și a genera antipatie față de Occident ${ }^{29}$. De asemenea, Kremlinul a amenințat direct cu utilizarea forței împotriva României în 2016, ca răspuns la decizia Bucureștiului de a găzdui infrastructura SUA, de apărare antirachetă pe teritoriul său ${ }^{30}$. Pentru România, riscul unei agresiuni hibride, venită din direcția Federației Ruse sau a potențialilor parteneri economici ai acesteia, crește odată cu lipsa unei minorități ruse sau proruse pe teritoriul românesc, precum și prin faptul că țara se află într-o zonă geografică în care Rusia are dreptul de a se exprima. De altfel, România este încă prizoniera deciziilor geostrategice luate de marile puteri militare aliate, conduse de Napoleon și de Alexandru I al Rusiei, în anul 1807, prin care au fost împărțite sferele de influență din Europa. Documentul obraznic ${ }^{31}$, cum este cunoscut acordul de procentaj care a statuat înţelegerea dintre Churchill și Stalin, de împărțire a Europei de Est în sfere de influență, nu a fost, de fapt, decât o reconfirmare a înţelegerii din Tratatul de la Tilsit (1807) dintre marile puteri estice și vestice ale începutului de secol al XIX-lea, care își disputau supremația asupra Europei.

Având în vedere schimbările de direcție strategică din 2014, este clar că Rusia își augmentează, într-un ritm accelerat, capacitatea militară din regiunea Mării Negre. Planul de reechipare a Flotei Mării Negre și a altor forțe din districtul militar sudic a precedat însă anexarea Crimeii și războiul din estul Ucrainei. Chiar dacă nu ar fi existat nicio mișcare de protest Euromaidan în Ucraina, Rusia ar fi introdus în înzestrarea forțelor armate proprii un număr mare de sisteme de armament moderne. Acest fapt se datorează faptului că liderii ruși consideră că, în orice condiții geopolitice, Rusia are nevoie de o armată care să descurajeze în mod credibil potențialele agresiuni externe și care să fie suficient de puternică pentru a constrânge actorii regionali, dacă este necesar.

Consider că Rusia a avut o strategie de securitate bine stabilită încă de dinainte de criză cu Ucraina. În special capacitățile sporite pentru districtul militar sudic, care făceau parte din Programul de armament de stat, început în 2011, ar fi asigurat depăşirea cantitativă a forțelor armate din zonă și, într-o anumită măsură, ar fi servit drept factor de descurajare împotriva intervenției occidentale, în cazul unei crize regionale. Descurajarea strategică este susținută, în primul rând, de forțele nucleare strategice ale Rusiei (rachete strategice, forțe strategice navale, aviație strategică și arme nucleare tactice), în timp ce descurajarea convențională împotriva NATO în regiunea Mării Negre ar putea implica o capacitate sporită de executare a unor lovituri în adâncime cu sisteme de armament de la suprafaţă sau din imersiune, cu capabilităţi A2/AD și cu celelalte forțe armate regulate din regiune. 
Anexarea Crimeii și deteriorarea corespunzătoare a relațiilor Rusiei cu Ucraina și cu Occidentul au modificat planul Rusiei pentru armata sa, în două moduri. În primul rând, anexarea Crimeii a permis Federației Ruse să realoce o cantitate considerabilă de capabilităţi militare la $300 \mathrm{~km}$ spre vest, pentru a spori flota și infanteria navală care erau deja acolo. Având în vedere starea actuală și, probabil, viitoare a relațiilor dintre Rusia şi Occident, această capacitate sporită ar permite Moscovei să amenințe NATO mai departe de centrul politic al Rusiei și de potenţialele teatre de operații militare, precum Ucraina, Caucazul de Sud și, într-o măsură mai mică, Moldova. Acest aspect este posibil, având în vedere teritoriul tampon cu limita frontierei NATO de-a lungul tuturor axelor, cu excepția sud-estului. Celălalt mod în care planul s-a schimbat pentru Rusia a fost repoziționarea și restructurarea unei cantități relativ mari de putere de luptă de-a lungul multor secțiuni din graniţa Rusiei cu Ucraina. În multe privințe, această repoziționare nu costă mult Rusia, având în vedere că amenințările majore la adresa securității provin, astăzi, din vestul Rusiei, iar forțele desfășurate de-a lungul frontierei cu Ucraina ar putea fi mutate spre nord, în cazul apariției unei crize acolo (deși, probabil, Rusia ar accepta un risc mai mare în Ucraina sau poate în Georgia, în funcție de numărul de forțe care au fost redistribuite). Această afirmație va rămâne valabilă atâta timp cât nu există fricțiuni majore între Rusia şi China, în ceea ce privește activitățile din Asia Centrală sau din Orientul Îndepărtat, care ar putea cere Rusiei să se bazeze pe forțele existente în acele zone.

În cazul declanșării unei crize în altă zonă, asigurarea flancului de sud-vest ar fi mai precară pentru Rusia decât pentru Uniunea Sovietică, care avea la dispoziţie un fond de resurse umane și financiare mult mai mare. Pragul pentru Rusia, care angajează aceste forțe nou concentrate pe teritoriul non-NATO, adiacent acesteia este, fără îndoială, destul de scăzut. Dovezile istorice, comportamentul și retorica rusă recentă sugerează că fostul spațiu sovietic este esențial pentru obiectivele politice, economice și de securitate ale Rusiei. Liderii ruși au afirmat în mod explicit, în mai multe ocazii, în discursuri, remarci şi documente strategice oficiale, că reintegrarea statelor fostei Uniuni Sovietice într-o formă sau alta este un obiectiv politic cheie ${ }^{32}$. Având în vedere acțiunile Rusiei în
Ucraina, începând cu anul 2014 - care, cel puțin într-o anumită măsură, au fost legate de încercarea Rusiei de a implica Ucraina în proiectul de integrare eurasiatică -, rămâne neclară disponibilitatea Rusiei de a accepta că Ucraina (precum şi Georgia, Moldova și Armenia) se află în afara acestor procese de integrare eurasiatică. Ceea ce pare a fi clar, astăzi, este că Rusia a recunoscut că unii dintre vecinii săi pot semna acorduri de asociere cu UE. Dar Moscova se va opune, cu siguranță, atât prin mijloace nemilitare, cât și militare (exclus asupra statelor membre ale NATO), oricărei integrări formale politice sau în special militare cu Occidentul, cum ar fi aderarea la NATO sau UE.

Din punct de vedere istoric, pierderea potenţială a unui aliat, reorientat spre Occident, a reprezentat casus belli pentru Rusia (și Uniunea Sovietică), deși acest lucru nu a condus întotdeauna la intervenție militară. De exemplu, nici Revoluția Trandafirilor din Georgia, în 2003, și nici Revoluția Portocalie din Ucraina, din 2004, nu au condus la acțiuni militare evidente ale Rusiei. Mai recent, revoluția populară din Armenia, din 2018 - care 1-a vizat pe Serzh Sargsyan, un aliat al Kremlinului, înlăturat de la putere și înlocuit de liderul revoluției -, nu a impus o intervenție în forță a armatei ruse. Pe de altă parte, războiul rusesc cu Georgia, din 2008, și intervenția Rusiei în Crimeea și în estul Ucrainei au avut loc în contextul potenţial de schimbare de direcție a acestor țări. Acestea au devenit prea occidentale pentru gustul protectiv și expansiv al Rusiei, deși circumstanțele au fost diferite în fiecare caz. În Georgia, Rusia a desfășurat trupe pentru a-și consolida controlul asupra Osetiei de Sud, pe care regimul Saakashvili îl ameninţa. În Ucraina, Rusia a trimis forțe în Crimeea abia după ce președintele ucrainean, Viktor Ianukovici, care era mai prietenos cu politica de la Moscova, a fugit din țară și s-a format un guvern proocidental, amenințând, potențial, interesele rusești, inclusiv baza navală din Crimeea.

În mod clar, decizia de a interveni militar este una mult mai complexă decât pare la prima vedere și poate depinde de mulţi factori și acțiuni, dintre care unii pot să nu provină din Moscova. Cu siguranță că există multe aspecte care nu sunt publice, despre deciziile Kremlinului cu privire la crizele menționate anterior. Cu toate acestea, se știe că nici Uniunea Sovietică și nici Federația Rusă nu au desfășurat forțe militare într-o țară NATO, cu 
intenţia de a pune mâna pe teritoriul acesteia sau de a schimba cu forța statu-quoul politic. De mai multe ori ${ }^{33}$, Moscova a desfășurat forțe în zone de interes strategic doar atunci când nu erau deloc sau erau puține şanse de intersectare cu forțe ale NATO.

Ca o excepție, intervenția Rusiei, din 2015, în Siria - unde au fost prezente trupele SUA și unde a existat o politică americană declarată, oricât de informală, împotriva continuării regimului Assad a fost, într-o oarecare măsură, un aspect anormal. Pe de altă parte, având în vedere numărul mic de forțe SUA prezente în Siria, Moscova era, se pare, relativ încrezătoare că războiul cu Statele Unite este puțin probabil. Public ${ }^{34}$, Putin a sugerat că Rusia a intervenit în Siria pentru a preveni răspândirea terorismului și pentru a exclude un rezultat-căderea guvernului sirian - care ar semăna $\mathrm{cu}$ acțiunile întreprinse de Occident în Iugoslavia, Irak și Libia ${ }^{35}$. Având în vedere o viitoare intervenție la scară largă în Ucraina sau în Caucazul de Sud, Moscova ar studia, probabil, posibilitatea și capacitatea NATO de a răspunde militar, pe lângă alte prognoze militare $^{36}$. În general, o schimbare (sau posibilitatea schimbării) în statu-quoul politic, în detrimentul intereselor rusești și în favoarea Occidentului, rămâne un indicator relativ fiabil, deși insuficient, al unei posibile intervenții militare rusești în regiunea Mării Negre. Aceasta nu exclude, însă, ca Rusia să intervină, folosind mijloace și instrumente hibride, sub limita detectabilităţii sau prin intermediul terților, pentru atingerea scopurilor.

\section{Concluzii}

Când Uniunea Sovietică s-a prăbușit, Federația Rusă a moștenit o influență considerabil mai mică în regiunea Mării Negre decât a avut-o predecesorul său sovietic, precum și mai puține resurse globale pentru a atenua amenințările percepute. În același timp, istoria recentă a demonstrat că interesele rusești în regiune au rămas în mare parte neschimbate, în special în ceea ce privește fostele republici sovietice. Această dinamică a adăugat un grad de urgență și tensiune regiunii care, probabil, a fost mai puțin intensă în timpul Războiului Rece, datorită influenței sovietice în capitalele statelor riverane și a zonei maritime mai mari controlate de flota militară rusă.

Interesele rusești se concentrează, în primul rând, pe dorința de a menține diferite niveluri de influență politică și economică în fiecare stat riveran, de a menține Marea Neagră sub control pentru exporturile de petrol sau gaze naturale și alte transporturi maritime prin portul Novorossiysk, precum și prevenirea unui deficit de securitate faţă de NATO, care ar putea ameninţa flancul de sud-vest al Kremlinului. Strategia Rusiei în urmărirea acestor interese se bazează pe utilizarea instrumentelor diplomatice, informaționale, politice, cibernetice și economice, care sunt susținute de o capacitate militară din ce în ce mai credibilă. Calculul Moscovei privind posibila utilizare a forței în regiunea Mării Negre este modelat de mulți factori.

În ceea ce privește posibilele elemente sau implicații ale unei strategii occidentale compensatorii, există cel puţin două aspecte cheie din cercetarea cuprinsă în acest articol. În primul rând, interesele rusești în regiune nu sunt aceleași pentru toate statele riverane. Relaţiile Rusiei cu membrii NATO (România, Bulgaria și Turcia) sunt secundare relațiilor sale cu Ucraina și Georgia. Gândindu-se la viitoarea politică faţă de aceste din urmă țări, Statele Unite și NATO trebuie să își determine propriul angajament, toleranța la risc şi prioritizarea politicii, ținând, în același timp, cont de posibilele reacții rusești.

În al doilea rând, deși nu este neapărat un premonitoriu al acţiunilor viitoare, comportamentul rus, în ultimele două decenii, a arătat că Rusia nu caută o confruntare militară cu NATO și se va strădui să evite orice scenariu care să implice o desfășurare pe scară largă a forțelor sale terestre. Acestea nu mai sunt nici structurate pentru a duce un război prelungit, pe scară largă, nici susținute de o economie mare (în raport cu cea a Occidentului). O intervenție militară la scară largă în regiunea Mării Negre, deși improbabilă, nu poate fi exclusă, dar aversiunea Rusiei de a expune o parte semnificativă a forțelor sale terestre sugerează că demonstrațiile continue și persistente ale coeziunii NATO și rezilienței politice în țările partenere NATO ar putea fi factori cheie în descurajarea, intimidarea și constrângerea rușilor în regiune.

În final, consider că poziționarea rusă asupra securității sugerează trei moduri importante în care liderii ruși privesc regiunea Mării Negre și strategia Rusiei în zonă.

Marea Neagră nu este o singură regiune importantă pentru asigurarea securității Federației Ruse, dar are importanța ei, raportată la confluența 
intereselor dintre Asia și Europa. În gândirea securității naționale rusești, Marea Neagră este o regiune distinctă, dar importanța acesteia nu primează față de alte regiuni la fel de importante, precum zona baltică. Cu siguranță, Marea Neagră are o caracteristică geografică singulară, cu implicații, ca mediu de operare, inclusiv porturi cu apă caldă. Dar tratarea mării și a naţiunilor din jur ca o singură regiune riscă să impună un cadru inexact al gândirii ruse.

Marea Neagră și statele riverane nu ocupă un anumit spațiu discret pe o listă generală a priorităților regionale rusești. Mai precis, zona este o intersecție a mai multor preocupări principale de securitate națională ale Moscovei, care variază în natură și intensitate. Cele mai importante dintre aceste preocupări sunt locurile pe care Rusia le consideră a fi aproape de casă (aproape în străinătate) și, prin urmare, integrate în propriul sentiment de identitate și securitate al Rusiei. Aceste zone includ toată Ucraina, Moldova și Georgia, Rusia lansând tot timpul pretenții asupra Crimeii, Abhaziei și Osetiei de Sud (inclusiv asupra Transnistriei), astfel încât acele teritorii au o rezonanță deosebit de profundă pentru spiritul rus. Atât Ucraina, cât și Georgia, în ansamblu, fac parte din strategia Rusiei de a controla cât mai multe regiuni circumscrise zonei extinse a Mării Negre. Moldova ocupă un loc aparte, distinct, deoarece lansarea unor agresiuni în regiune ar implica traversarea Ucrainei, ceea ce ar expune prea mult forțele ruse.

Într-un sens mai practic, Marea Neagră este importantă datorită proiecției puterii și accesului semnificativ pe care îl oferă Rusiei - în special, accesul la rutele maritime globale de comerț și comunicare, oportunităţile de proiecție a puterii la distanță strategică, precum și la extinderea apărării aeriene și de coastă. Axa est-vest care traversează Marea Neagră dinspre Caucaz înspre Balcani reprezintă nodul strategic comercial și o placă turnantă a schimburilor comerciale dintre Asia și Europa.

De asemenea, motivul preocupărilor de securitate națională ale Rusiei este reprezentat de apropierea forțelor NATO și de operațiile militare ale acestora, în zonele de proximitate ale Rusiei. În viziunea Kremlinului, regiunea prezintă riscuri pentru securitatea Rusiei. Orice provocare pentru Abhazia sau Crimeea - sau pentru restul Georgiei sau Ucrainei - afectează direct și intim sentimentul de siguranță al Rusiei. Pretenția Federației Ruse de a i se recunoaște statutul de mare putere într-o hegemonie multipolară, parțial prin rolurile sale de protector al Crimeii, Abhaziei și Osetiei de Sud, de furnizor de soluții în Donbas, dar și ca mare putere în zona extinsă a Mării Negre reprezintă un risc pentru stabilitatea acesteia, în situaţia în care nu va reuși să-și mențină dominația în această regiune.

\section{NOTE:}

1 https://winstonchurchill.org/resources/speeches/ 19461963-elder-statesman/the-sinews-of-peace/, accesat la 17.03.2021.

2 https://learning.blogs.nytimes.com/2012/03/05/march-51946-winston-churchill-warns-of-soviet-iron-curtain/, accesat la 17.03.2021.

$3 \mathrm{http}: / / \mathrm{cpc}-\mathrm{ew} . \mathrm{ro} / \mathrm{pdfs} /$ politica_energetica_a_rusiei.pdf, accesat la 26.05.2021.

4 Războiul Crimeii din 1853, purtat între Rusia și alianța formată din Imperiul Otoman, al doilea Imperiu Francez, Regatul Unit al Marii Britanii și Irlandei și regatul Sardiniei.

5 Războiul polono-rus, din perioada 1605 - 1618, a fost reprezentat de o serie de conflicte militare dintre țaratul rus și uniunea polono-lituaniană, care a profitat de haosul intern, generat de desele războaie civile, declanşate de interimatul la conducerea țaratului, de după moartea țarului Fiodor I, din 1598, prin transferul puterii de la dinastia Rurik (1598) la dinastia Romanovilor (1513), perioadă denumită timpurile tulburi ale Rusiei.

6 Marele război al Nordului din perioada 1700-1721, purtat între trupele suedeze și cele ale coaliției, formată din Danemarca, Polonia și Rusia.

7 Campania lui Napoleon din 1812, care, deși cucerește Moscova, în realitate, a ajuns să fie cel mai mare dezastru din campaniile napoleoniene. Pierderile militare au fost de aproximativ 300.000 de francezi, 70.000 de polonezi, 50.000 de italieni, 80.000 de germani și, probabil, 450.000 de ruşi. Francezii au mai pierdut aproximativ 200.000 de cai și peste 1.000 de piese de artilerie.

8 https://www.historia.ro/sectiune/general/articol/napo leon-wehrmacht-ul-si-capricioasa-vreme-din-rusia, accesat la 18.03.2021.

9 1568-1570, 1676-1681, 1686-1700, 1710-1711, 1735$1739,1768-1774,1787-1792,1806-1812,1828-1829,1853-$ 1856, 1877-1878, 1914-1918.

10 Potențialul economic al regiunii Mării Negre fusese descoperit pentru prima oară de coloniștii greci, ulterior de romani și bizantini, apogeul economic al regiunii fiind atins în timpul expansiunii comerciale a republicilor italiene genoveze și venețiene.

11 Anexată iniţial de Rusia prin Tratatul de pace de la București, din 1812, urmare încheierii războiului ruso-turc din 1806-1812.

12 http://www.bbc.co.uk/romanian/news/story/2008/04/ 080401_bush_bucuresti.shtml, accesat la 18.03.2021.

$13 \mathrm{https}: /$ georgewbush-whitehouse.archives.gov/news/ releases/2008/04/20080402-2.html, accesat la 18.03.2021. 
14 http://www.cpc-ew.ro/pdfs/razboiul_ruso_georgian. pdf, accesat la 18.03.2021.

15 https://www.youtube.com/watch?v=hQ58Yv6kP44, accesat la 18.03.2021.

16 Nagorno-Karabah este un teritoriu disputat, recunoscut la nivel internaţional ca parte a Azerbaidjanului, dar în cea mai mare parte guvernat de Republica Artsakh, nerecunoscută (denumită anterior Republica Nagorno-Karabah (NKR) de la primul război din Nagorno-Karabah. Aceasta este o regiune fără ieșire la marea din Caucazul de Sud, situată în zona montană a Karabakhului, între Karabakhul de Jos și Zangezur, acoperind zona de sud-est a munților Caucazului Mic.

17 Uniunea Economică Euroasiatică (EEU), înființată la 18 noiembrie 2011, a fost concepută de președintele rus Vladimir Putin ca o alternativă la piața Uniunii Europene, fiind însă departe de a oferi avantajele economice ale acesteia. Pe lângă cele 5 state menționate, în 2019 s-a alăturat și Serbia.

18 Este o alianță militară interguvernamentală care a fost înființată la 15 mai 1992. Uzbekistan a intrat în organizație la data înființării acesteia, dar a ieșit în 1997. A reintrat, ulterior, în 2006, dar s-a retras din OTSC în 2012.

$19 \mathrm{Cu}$ excepția Albaniei.

$20 \mathrm{https}: / / w w w . n a t o . i n t / n a t o \_s t a t i c / a s s e t s / p d f / p d f \_2014$ 07/20140716_140716-Factsheet_Russia_en.pdf, accesat la 26.05.2021.

21 Forța de menținere a păcii, susținută de guvernul american-egiptean-izraelian, constituită la 3 august 1981 .

22 Stephen J. Flanagan \& others, Russia, NATO, and Black Sea Security, RAND Corporation, Santa Monica, California, 2020, https://www.rand.org/content/dam/rand/pubs/ research_reports/RRA300/RRA357-1/RAND_RRA357-1.pdf, accesat la 19.03.2021.

$23 \mathrm{https} / / / \mathrm{www} . \mathrm{dw} . \mathrm{com} /$ ro/ucraina-starea-de-r\% $\%$ C4\%83zboi -este-iminent $\%$ C4\%83/a-46460018, accesat la 09.03.2021.

24 https://www.dailysabah.com/business/2019/04/09/ turkey-russia-seek-new-ways-to-reach-100b-in-bilateraltrade, accesat la 26.05.2021.

$25 \mathrm{https}$ //eurasianet.org/how-has-conflict-with-russiaaffected-ukraines-trade; și Stephen J. Flanagan \& others, 2020 , p. 49.

$26 \mathrm{https}: / / w w w . e c o n o m i c a . n e t / r u s i a-p r e g a t e s t e-s a n c t i u$ ni-economice-dure-contra-turciei-erdogan-vrea-indreptareaerorilor-facute-de-ambele-parti_110874.html, accesat la 19.03.2021.

27 https:/www.europarl.europa.eu/RegData/etudes/ IDAN/2017/578016/EXPO_IDA\%282017\%29578016_ EN.pdf, accesat la 26.05.2021.

28 Vesti, „Miroporyadok: Dokumental'nyi fil'm Vladimira Solov'eva [World Order: Documentary by Vladimir Solov'ev]," video, YouTube, 20 decembrie 2015. Ca răspuns la o întrebare referitoare la relațiile dintre Rusia și Occident în ceea ce privește Ucraina și alte probleme, Putin a răspuns: „În ceea ce privește Ucraina și, în general, spațiul post-sovietic, sunt convins că poziția partenerilor noștri occidentali - europeni și americani - nu se concentrează pe protejarea intereselor Ucrainei. Dar, mai degrabă, (poziţia lor) este legată de o tentativă de a întrerupe încercarea de a recrea Uniunea Sovietică. Și nimeni nu vrea să creadă că nu avem un scop, de a recrea Uniunea Sovietică. Dar există posibilitatea de a se uni (a fostelor republici sovietice) în cadrul proceselor moderne de integrare economică (vreau să subliniez acest cuvânt), care ar face, fără îndoială, Rusia și Ucraina mai competitive în economia globală și care ar permite Rusiei şi Ucrainei să-și ocupe locurile corespunzătoare în sistemul modern de diviziune a muncii pe piețele globale. Chiar și această posibilitate nu le permite partenerilor noștri să doarmă profund și cred că sarcina principală (a Occidentului) este de a întrerupe această îmbinare a efortului. De ce se poate forma Uniunea Europeană, dar Uniunea Eurasiatică, nu?"

29 Raphael S. Cohen, Andrew Radin, Russia's Hostile Measures in Europe: Understanding the Threat, CA: RAND Corporation, Santa Monica, 2019, p. 67, https:/www.rand. org/content/dam/rand/pubs/research_reports/RR1700/ RR1793/RAND_RR1793.pdf, accesat la 19.03.2021.

30 În urma activării sistemului antirachetă, Putin a avertizat: „Acum suntem obligați să reacționăm într-o manieră corespunzătoare și dacă ieri acele părți ale teritoriului României nu știau cum este să fii în vizor... atunci astăzi va trebui să recurgem la anumite acțiuni care să ne asigure securitatea", https://www.youtube.com/watch?v=w1U4E QwWpg, accesat la 19.03.2021.

31 https:/www.telegraph.co.uk/news/2019/04/02/ winston-churchills-naughty-document-written-stalin-godisplay/, accesat la 26.05.2021.

32 https://www.youtube.com/watch? $\mathrm{v}=\mathrm{sV}-8 \mathrm{RxtQtcw}$, accesat la 19.03.2021.

33 Ungaria -1956; Cehoslovacia-1968; Afganistan1979; Georgia-2008; Crimeea-2014; estul Ucrainei-2014.

$34 \mathrm{https}: / /$ www.youtube.com/watch?v=6ly2n94izbI, accesat la 19.03.2021.

35 Vladimir Putin, Intâlnirea Clubului internațional de discuții Valdai, 22 octombrie 2015; Vladimir Putin, Întâlnirea Clubului internaţional de discuții Valdai, 27 octombrie 2016.

36 Stephen J. Flanagan \& others, Russia, NATO, and Black Sea Security, RAND Corporation, Santa Monica, California, 2020, https://www.rand.org/content/dam/rand/pubs/ research_reports/RRA300/RRA357-1/RAND_RRA357-1.pdf, accesat la 19.03.2021, p. 72.

\section{BIBLIOGRAFIE}

Benedyczak Jakub, "The Importance of Turkey in Russian Policy", Polski Instytut Spraw Międzynarodowych Bulletin (The Polish Institute of International Affairs), 2020.

Binnendijk Anika, Understanding Russian Black Sea Power Dynamics Through National Security Gaming, Published by the RAND Corporation, Santa Monica, California, 2020.

Brister Paul, "Revisiting the Gordian Knot: Strategic Considerations for Hybrid Warfare", Hybrid Warfare and Transnational Threats: Perspectives for an Era of Persistent Conflict, eds., Paul Brister, William H. Natter, Robert R. Tomes, Council for Emerging National Security Affairs, New York, 2011. 
Brusylovska Olga, Dubovyk, Volodymyr, and Koval, Igor (eds.), Black Sea Region in World Policy: Actors, Factors, and Scenarios of the Future, Odesa Mechnikov National University Press, Odesa, 2020.

Brzezinski Zbigniew K, The grand chessboard: American primacy and its geostrategic imperatives / 1928 (reed 1997), Basic Books, A Member of the Perseus Books Group, 1st ed.

Chifu Iulian, Nantoi Oazu, Război informațional. Tipizarea modelului agresiunii, Editura Institutului de Ştiințe Politice și Relații Internaționale I.C. Brătianu, București, 2016.

Diaconescu L., „Insula Lumii - Mutarea Centrului Strategic Mondial de la Heartland la Oceanul Indian”, Revista Română de Geografie Politică, 22 (1), 2020.

Dughin Aleksandr, Teoria lumii multipolare, Universitatea Populară, Chișinău, 2014.

Flanagan J. Stephen \& others, Russia, NATO, and Black Sea Security, RAND Corporation, Santa Monica, California, 2020, https://www.rand.org/ content/dam/rand/pubs/research_reports/RRA300/ RRA357-1/RAND_RRA357-1.pdf

Freedman Lawrence, Viitorul războiului. O istorie, Editura Litera, București, 2019.

Friedman George, Puncte de presiune. Despre viitoarea criză din Europa, Editura Litera, București, 2016.

Hoffman Frank, "The Hybrid Character of Modern Conflict", Hybrid Warfare and Transnational Threats: Perspectives for an Era of Persistent Conflict, eds., Paul Brister, William H. Natter, Robert R. Tomes, Council for Emerging National Security Affairs, New York, 2011.

Ioniță Liviu, „Dimensiunea hibridă a conflictului ruso-ucrainean", Buletinul Universităţii Naţionale de Apărare „Carol I” nr. 3, 2015.

Jacek Reginia-Zacharski, Ukrainian issues in geopolitical thought of the twentieth and twenty first centuries, Editura Universității din Lodz, 2016.

Jenkins Simon, Scurta istorie a Europei, de la Pericle la Putin, Editura Litera, București, 2019.

Kaplan D. Robert, Fantomele Balcanilor $o$ călătorie in istorie, Editura Antet, București, 2008.

Kaplan D. Robert, Răzbunarea geografiei. Ce ne spune harta despre conflictele viitoare și lupta impotriva destinului, Editura Litera, București, 2015.
Kondratenko Oleg, Ukraine as a Geopolitical Priority of the Russian Federation, Universitatea Națională de Aviație, Kiev, Ucraina, 2016.

Mackinder J. Halford, Democratic Ideals And Reality - A Study in the Politics of Reconstruction, NDU Press Defense Classic Edition, 1942.

Maior George, Sergei Konoplyov, Cunoaștere strategică în zona extinsă a Mării Negre, Editura RAO, București, 2011.

Marshall Tim, Prizonierii geografiei, Editura Litera, București, 2020.

Massie K. Robert, Petru cel Mare. Viața și lumea lui, Editura ALL, București, 2015.

Meyers Steven Lee, Noul Țar, Corint Books, București, 2016.

Orzechowski Marcin, The Russian Federation's neo-imperial expansionist strategy for the PostSoviet region discussed using the example of the Russo-Georgian conflict of 2008, Reality of Politics. Estimates - Comments - Forecasts 9/2018:30-43, https://www.ceeol.com/search/artic le-detail?id=772494

Siudak Michał, "Geopolityczne Wizje Krymu I Ukrainy", Przeglad Geopolityczny 18.

Stancu Mihai-Cristian, „Războiul informațional. Studiu de caz: Rolul «Rusia Today» pentru acoperirea misiunii executate de către Federația Rusă în estul Ucrainei, în perioada mai 2014februarie 2015", Buletinul Universității Naționale de Apărare „, Carol I” Nr. 4/2019.

Ünalmiş Ahmet Nafiz, Şafak Oğuz, 2008 Rusya-Gürcistan Savaşının Vekalet Savaşı Teorisi - The Investigation of 2008 Russia-Georgia War in Terms of the Theory of Proxy War, Açisindan İncelenmesi. Karadeniz Araştırmaları 61/2019:3141, https://www.ceeol.com/search/article-detail?id $=782070$

Urban Jakša, "EU Policy Options Towards Post-Soviet De Facto States", Polski Instytut Spraw Międzynarodowych (The Polish Institute of International Affairs), nr. 6 (159), octombrie 2017.

Ven Bruusgaard Kristin, Challenges in Russia \& Afghanistan. Crimea and Russia's Strategic Overhaul, Army Strategic Studies Institute, 2014.

Waseem Ahmad Qureshi, The Rise of Hybrid Warfare, 10 NOTRE DAME J. INT'L \& COMP. LAW 173 (2020).

Wojciech Lorenz, Strengthening Deterrence in the Black Sea Region, Polski Instytut Spraw Międzynarodowych (The Polish Institute of International Affairs), 2017. 
Wojciech Łysek, Crimea in great powers foreign policy: bordeland-conflict-destabilization, Polskie Towarzystwo Geopolityczne, 2015.

https://winstonchurchill.org/resources/speeches/ 1946-1963-elder-statesman/the-sinews-of-peace/

https://learning.blogs.nytimes.com/2012/03/05/ march-5-1946-winston-churchill-warns-of-sovietiron-curtain/

http://cpc-ew.ro/pdfs/politica_energetica_a_ rusiei.pdf

https://www.historia.ro/sectiune/general/arti $\mathrm{col} /$ napoleon-wehrmacht-ul-si-capricioasa-vremedin-rusia

http://www.bbc.co.uk/romanian/news/story/ 2008/04/080401_bush_bucuresti.shtml

https://georgewbush-whitehouse.archives.gov/ news/releases/2008/04/20080402-2.html

http://www.cpc-ew.ro/pdfs/razboiul_ruso georgian.pdf $6 \mathrm{kP} 44$ https://www.nato.int/nato_static/assets/pdf/ pdf_2014_07/20140716_140716-Factsheet Russia en.pdf

https://www.dailysabah.com/business/2019/

04/09/turkey-russia-seek-new-ways-to-reach100b-in-bilateral-trade

https://eurasianet.org/how-has-conflict-withrussia-affected-ukraines-trade

https://www.economica.net/rusia-pregatestesanctiuni-economice-dure-contra-turciei-erdoganvrea-indreptarea-erorilor-facute-de-ambeleparti_110874.html

https://www.europarl.europa.eu/RegData/etudes/ IDAN/2017/578016/EXPO_IDA\%282017\%295 78016_EN.pdf

https://www.telegraph.co.uk/news/2019/04/ 02/winston-churchills-naughty-document-writtenstalin-go-display/

https://www.dw.com/ro/ucraina-starea-der\%C4\%83zboi-este-iminent\%C4\%83/a-46460018 